NBER WORKING PAPER SERIES

\title{
LENDING WITH COSTLY ENFORCEMENT \\ OF REPAYMENT AND POTENTIAL FRAUD
}

Jonathan Eaton

Working Paper No. 1697

\author{
NATIONAL BUREAU OF ECONOMIC RESEARCH \\ 1050 Massachusetts Avenue \\ Cambridge, MA 02138 \\ September 1985
}

Presented at the International Colloquim in Memory of Daniel

Recanati on the Banking Industry in a Changing Financial

Environment, Kibbutz Ma'ale Hachamisha, Israel, June 10-12, 1985. I am grateful to the National Science Foundation for support under grant number SES-8410613. The research reported here is part of the NBER's research program in International Studies and project in Productivity and Industrial Change in the World Economy. Any opinions expressed are those of the author and not those of the National Bureau of Economic Research. 
Lending with Costly Enforcement of Repayment and Potential Fraud

\section{$\underline{\text { ABSTRACT }}$}

If contracts are costlessly enforcible then insolvency is the only reason for nonrepayment of loans. While some models have examined the borrower's incentive to repay, it has typically been assumed that the penalty suffered by a debtor in default is imposed automatically and without cost to the lender. If in fact invoking a penalty is costly, Pareto-improving loans may be dynamically inconsistent not because of the absence of a sufficiently harsh penalty for default, but because the lender has no incentive actually to implement the penalty in the event of default. In such situations infinitelylived institutions can emerge as banking intermediaries between lenders and borrowers. These institutions, repeatedly involved in lending, have an incentive to enforce contracts that individual lenders lack. They can consequently sustain more lending. For their reputations as enforcers of contracts to have value requires that banks earn strictly positive profits. Maintaining the value of bank equity also provides an incentive for bank owners to invest deposits rather than to use these funds fraudulently. Because of the supernormal profits that banks must earn, an equilibrium that is sustained by bank reputation will not replicate an equilibrium in which loan repayment is automatically guaranteed. 
1. Introduction

Most analysis of financial markets posits that contracts are costlessly enforcible. The borrower's insolvency is consequently the only reason for nonrepayment of debt. In a domestic context a creditor typically has access to a legal system to gain control of the assets of a borrower in default. The borrower thus has no incentive to default if he does in fact have resources to make payment. The value of the borrower's assets limits the lender's loss if default should occur.

In some contexts, particularly in international financial markets, a creditor's ability to use the courts to gain ownership of the assets of a borrower in default is much more limited. Where major net movements of capital across borders are involved, most of the borrower's assets lie outside the jurisdiction of the creditor's government. The incentive of the borrower's government to enforce repayment or transfer assets is much more limited, especially if the borrower in default is the government itself. In fact, lenders' inability to obtain control of the assets of borrowers in default has led to a great deal of concern over the value of sovereign loans to several developing countries. These countries have assets whose value is clearly far in excess of their outstanding debts, but their willingness to pay these debts is in some doubt. In the absence of a military intervention that is unlikely, lenders have no means of gaining control of these assets should repayment not occur.

Nevertheless, lenders have extended loans under these circumstances and borrowers have serviced debt. Clearly both types of agents perceive that borrowers will suffer adverse consequences from nonpayment. In fact, foreign borrowers in default may lose further access to credit markets. Their ability 
to smooth consumption and to finance investment and trade is consequently hampered. 1

This type of penalty, unlike a transfer of assets to creditors, does not benefit the creditors. In fact, imposing such a penalty may be costly to them as well as to borrowers. The existence of such penalties replaces one paradox, why debtors repay, with another, why creditors impose penalties on borrowers in default.

This paper develops a model of financial markets in which creditors' control over their debtors: assets is i imited. In the presence of costiy enforcement of contracts or of potential fraud, any direct transfers between lenders and borrowers would not be viable, even though they would increase the welfare of both types of agents. Financial institutions, repeatedly involved in lending, have an incentive to enforce contracts that individual lenders lack. They can consequently sustain some lending. For their reputations as enforcers of contracts to have value requires that they earn a profit strictly above zero. An equilibrium in which bank reputation supports loan contracts will not, as a consequence, replicate an equilibrium in which loan repayment is automatically guaranteed.

The analysis here uses a variant of Samuelson's (1958) pure consumption loan model. Each agent is economically active for two periods. One type, called lenders, earns income only in the first period; another, called borrowers, only in the second. Both derive positive utility from consumption in both periods. A temptation naturally arises for lenders to lend to borrowers. 2

The first part of the analysis treats the incomes of both types of agents as exogenous. Borrowers experience a penalty if they do not repay, but imposing the penalty is costly for lenders. 
At first, it is assumed that the penalty is imposed automatically in the event of default. Direct lending from lenders to borrowers is then viable. If the penalty is sufficiently high lending in the amount that would occur if repayment were guaranteed is possible. This equilibrium is consequently attained. Otherwise, the impact of the penalty will constrain what borrowers owe in the repayment period. ${ }^{3}$ Lenders always benefit from an increase in the penalty. The effect on borrowers depends upon the elasticity of loan supply. If loans are supplied elastically they benefit from a high penalty; if loan supplies are interest inelastic they lose.

It is then assumed that the lender chooses whether or not to invoke the penalty in the event of default when default occurs. If it is costly to implement the penalty an individual lender would not do so. The threat to impose the penalty is therefore not credible, so the borrower has no reason to repay. The lender, aware that he will not recover any loan, lends nothing in the first place.

A financial institution called a bank is introduced that intermediates between lenders and borrowers. It issues equity to lenders, accepts deposits from them, and lends to borrowers. If loans are repaid then deposits are withdrawn and equity holders in the bank can sell their equity at a positive value to lenders of the next generation, since the institution has maintained its reputation for collecting loans. If loans are not repaid and no penalty is imposed then the institution loses its reputation and the value of its equity is zero. If the penalty is imposed, however, equity value is maintained. Maintaining the value of bank equity thus provides an incentive for the owners of banks to penalize borrowers in default. The threat to impose the penalty is made credible.

For bank equity to have value requires that banks earn excess profits. 
The interest rate on loans consequently exceeds that on deposits. Even if credit is not rationed the equilibrium that would emerge if repayment were guaranteed automatically is not replicated. 4

Finally, production is introduced. Lenders are workers who receive a wage in the first period of their lives. Borrowers are firms that borrow to invest in capital and hire workers to produce output. Banks intermediate between workers and firms. Workers can become investors in bank deposits or owners of banks. Maintaining the value of bank equity provides the incentive for bañkêrs tó invest deposits in firms rather than to consume them. Âgain, for bank equity to have strictly positive value requires that the marginal product of capital, what banks earn on loans, exceeds the deposit rate. Since investment in bank equity absorbs some workers' saving, the capital-labor ratio, output and wage are lower in an equilibrium in which repayment is sustained by bank reputation in comparison with an unconstrained equilibrium.

The outline of the paper is as follows: Section 2 describes the basic assumptions of the model and characterizes equilibrium when penalizing nonpayment is automatic. A penalty that must be invoked by lenders at a cost, so that lending requires the intermediation of banks, is considered in section 3. Section 4 treats lending by workers to firms when there is a potential for fraud. Some concluding remarks appear in section 5 .

\section{An Equilibrium with Direct Lending}

Two types of individuals, lenders and borrowers, have endowments over two periods given by $\left(w^{\ell}, 0\right)$ and $\left(0, w^{b}\right)$, respectively. They attain levels of utility $v^{\ell}$ and $v^{b}$ that are increasing, differentiable and quasi-concave functions of their consumption levels in the two periods, $\left(c_{i}^{y}, c_{i}^{0}\right)$, 
where $i=\ell$ for lenders and $i=b$ for borrowers. The number of lenders is normalized at one; there are $\mathrm{n}$ borrowers.

\subsection{The Unconstrained Equilibrium}

If lenders and borrowers can enter into loan contracts that are automatically enforcible then a competitive equilibrium will establish a loan amount $\ell^{\star}$ and an interest rate $r^{\star}$ that satisfy the two equations

$$
\begin{aligned}
& \frac{v_{y}^{l}\left(w^{l}-l^{\star},\left(1+r^{\star}\right) l^{\star}\right)}{v_{0}^{l}\left(w-l^{\star},\left(1+r^{\star}\right) l^{\star}\right)}=1+r^{\star} \\
& \frac{v_{y}^{b}\left[l^{\star} / n, w^{b}-\left(1+r^{\star}\right) l^{\star} / n\right]}{v_{0}^{b}\left[l^{\star} / n, w^{b}-\left(1+r^{\star}\right) l^{\star} / n\right]}=1+r^{\star}
\end{aligned}
$$

$l^{\star}$ and $r^{\star}$ will be referred to as the unconstrained loan amount and interest rate.

If $P$ denotes the penalty of nonrepayment in terms of second period consumption then the unconstrained equilibrium is enforcible as long as

$$
P \geq\left(1+r^{\star}\right) \ell * / n
$$

\subsection{The Rationed Equilibrium}

If condition (3) is not satisfied, then lenders will ration credit. Equilibrium will be characterized by a loan amount $\bar{l}$ and an interest rate $\bar{r}$ 
that satisfy

$$
\begin{gathered}
P=(1+\bar{r}) \bar{l} / n \\
\frac{v_{y}^{l}\left[w^{\ell}-\bar{l},(1+\bar{r}) \bar{l}\right]}{v_{0}^{l}\left[w^{l}-\bar{l},(1+\bar{r}) \bar{l}\right]}=1+\bar{r}
\end{gathered}
$$

Total lending is constrained by a repayment ceiling nP. Competition among lenders for solvent borrowers will drive the interest rate to the point at Which lenders are satisfied to lend $\pi p /(1+\bar{r})$ at an interest rate $1+\bar{r}$. This equilibrium is referred to as the rationed equilibrium.

To compare the interest rate, the amount lent, and welfare in the unconstrained and rationed regimes, consider an equilibrium in which $n P=\left(1+r^{\star}\right) \ell^{\star}$, so that the unconstrained equilibrium is just enforcible, and examine the effect of a reduction in $P$. Three results follow:

Proposition 1: The interest rate is lower in the rationed equilibrium than in the unconstrained equilibrium and the interest rate decreases when the penalty of default decreases.

Proof: Since expression (5), the lender's first-order condition for optimal lending, is satisfied in both equilibria, $\frac{d \ell}{d P}=\left.\frac{d \ell}{d r}\right|_{s} \frac{d r}{d P}$, where $\left.\frac{d \ell}{d r}\right|_{s}$ is the change in loan supply resulting from an increase in the interest rate. Differentiating condition (4) with respect to $P$, using this relationship, gives

$$
\left[\left.(1+r) \frac{d \ell}{d r}\right|_{s}+\ell\right] \frac{d r}{d P}=n
$$

As long as lenders' consumption in the retirement period is non-inferior, 
$(1+r) \ell$ increases when $r$ increases. Consequently $(1+r) \frac{d \ell}{d r}+\ell$ is positive. Hence $\frac{d r}{d P}$ is also.

The interest rate consitutes lenders' terms of trade. From Proposition 1 immediately follows

Proposition 2: Lenders' welfare is lower in the rationed equilibrium than in the unconstrained equilibrium. Their welfare rises as the penalty of default rises.

Finally

Proposition 3: Borrowers' welfare can be higher or lower in the rationed equilibrium, and they can benefit or lose from an increase in the penalty $P$. For the unconstrained equilibrium to be preferred, and for an increase in the penalty to raise their welfare, requires that loan supply be positively interest elastic.

Proof: In a rationed equilibrium a borrower's lifetime utility is $v^{b}\left(\ell / n, w^{b}-P\right)$. Differentiating with respect to $P$ gives

$$
\frac{d v^{b}}{d P}=\left.\frac{1}{n} v_{y}^{b} \frac{d \ell}{d r}\right|_{s} \frac{d r}{d P}-v_{0}^{b}
$$

which is negative unless $\left.\frac{d l}{d r}\right|_{s}$ is strictly positive. Jaffee and Russell (1976), Eaton and Gersovitz (1981a) and Sachs (1984) have partial equilibrium models in which the borrower always benefits from an increase in the penalty for default. They treat the lenders' interest rate as a constant, so that the term $\left.\frac{d \ell}{d r}\right|_{s}$ is implicitly infinity. If loan supply to borrowers as a group is more inelastic an increase in the default penalty 
can act to borrowers' detriment.

\section{A Banking Equilibrium}

The previous section assumed that the default penalty is invoked automatically or that the lender finds it in his interest to impose the penalty, presumably because the amount of the debt recovered exceeds the cost of implementing it. A borrower in default in many circumstances can prevent a lender from recovering much of his loan. For example, he may consume $w^{b}$ as $i t$ is received, before the lender can seize it. In these cases the individual lender has no incentive to impose the penalty if doing so is costly. Aware of this, the borrower has no incentive to repay. In turn, the lender's knowledge of the borrower's awareness removes any incentive to lend in the first place. Equilibrium degenerates to autarky.

If the lender expected to lend again, and there were no finite upper bound on the number of times he expected to lend again, the desire to maintain a reputation for punishing default could serve as an incentive to punish current nonrepayment. In this model, individual lenders anticipate lending only once, however. There is no incentive to maintain a reputation to punish default.

In this context a situation emerges in which finitely-lived individuals can establish infinitely-lived corporate entities to act as banking intermediaries. If these banks earn positive profits their equity will have value. Owners of equity in banks then have an incentive to enforce repayment to maintain the value of their equity.

Let $q_{t}$ denote the value of bank equity at time $t$. At the end of period $t$ lenders invest their savings in bank deposits (in amount $d_{t}$ ) which promise a 
return $r_{t}^{\prime}$, and in bank equity (worth $q_{t}$ ). Banks lend deposits to borrowers at a rate $r_{t}$. At the end of period $t+1$, if repayment occurs, banks receive $\left(1+r_{t}\right) d_{t}$ from borrowers, pay depositors $\left(1+r_{t}^{\prime}\right) d_{t}$, and distribute $\left(r-r^{\prime}\right) d_{t}$ to bank shareholders as a dividend. Shareholders sell their equity to young lenders for $q_{t+1}$. If borrowers default then banks in turn default on deposits and there is no dividend. If default is left unpunished the bank loses its reputation to enforce repayment. The value of bank equity becomes zero. If the bank imposes the penalty, even though current loans are not repaid, the bank's reputation is maintained. Even though deposits are defaulted upon and there is no dividend, the value of bank equity remains positive, since a promise to pay future dividends is credible. Faced with a borrower in default, owners of a bank must decide whether to incur the cost of punishment, thereby maintaining the value of their equity, or to avoid the punishment cost but lose the value of their equity investment in the bank. If $q_{t}$ denotes the value of a bank that at the end of period $t$ has maintained a reputation to punish default and $P^{\prime}$ denotes the cost of imposing the penalty on a borrower, then the choice will depend upon whether $q_{t} \geqslant n P^{\prime}$.

The value of a bank with a reputation to enforce repayment is the discounted value of the divident stream that the bank generates:

$$
q_{t}=\sum_{\tau=t}^{\infty} \frac{\left(r_{\tau}-r_{\tau}^{\prime}\right) d_{\tau}}{\tau}
$$

The deposit rate $r_{j}^{\prime}$ is the relevant discount rate since lenders invest either in bank equity or in deposits.

Lenders' saving each period takes the form of deposits and bank equity, so that 


$$
w^{\ell}-c_{l}^{y}\left(w^{\ell}, r_{t}^{\prime}\right)=d_{t}+a_{t}
$$

Either $a_{t} \geq n P^{\prime} \forall_{t}$ or else for any $\tau$ when $q_{\tau}<n P^{\prime}, q_{t}=0$ for $t \leq \tau$.

A steady state is characterized by constant values of the interest rates on deposits and loans, $\vec{r}^{\prime}$ and $\vec{r}$, respectively, a deposit amount, $\vec{a}$, and a value of bank equity, $\bar{q}$, that satisfy

$$
\begin{gathered}
\bar{q}=\frac{\left(\bar{r}-\bar{r}^{\prime}\right) \bar{d}}{\bar{r}^{\prime}} \\
w^{l}-c_{l}^{y}\left(w^{l}, \bar{r}^{\prime}\right)=\bar{q}+\bar{d} \\
\bar{q} \geq n P^{\prime} \\
v_{y}^{b}=(1+\bar{r}) v_{0}^{b} \text { if }(1+\bar{r}) \bar{d}<n P \\
v_{y}^{b}>(1+\bar{r}) v_{0}^{b} \text { if }(1+\bar{r}) \bar{d}=n P .
\end{gathered}
$$

Competition among banks in setting $r^{\prime}$ to attract depositors and $r$ to attract borrowers will insure that condition (12) holds with equality, since, given $r, r^{\prime}$ falls as q rises.

The two interest rates are consequently related by the expression

$$
\bar{r}=\frac{\bar{d}+n P^{\prime}}{\bar{d}} \bar{r}^{\prime}
$$

the difference between them rises as the cost of imposing the punishment rises relative to total deposits. 


\subsection{An Unconstrained Banking Equilibrium}

When condition (13) is an equality then the default penalty does not constrain the amount borrowed. A small change in P will then, of course, have no effect. The effect in steady state of a change in $\mathrm{P}^{\prime}$ on the welfare of borrowers and lenders can be determined solely by its effects on $r$ and $r^{\prime}$.

A change in $\mathrm{P}^{\prime}$, from condition (12), requires a proportional change in the value of bank equity. Given $\bar{r}^{\prime}$, and hence $\bar{q}+\bar{d}$, $d$ must fall by $n \Delta P^{\prime}$, so $\bar{r}$ rises by $\frac{\bar{r}^{\prime}}{\bar{d}} n \Delta P^{\prime}$. If borrowers' loan demand has a unit interest elasticity $\left(-\left.\frac{\partial d}{\partial r} \frac{r}{d}\right|_{b}=1\right)$ then in fact $\bar{r}^{\prime}$ and $\bar{d}+\bar{q}$ do not change. Lenders are consequently indifferent to the increase in $P^{\prime}$ while borrowers are harmed. If the borrowers' loan demand elasticity exceeds one then there is an excess supply of loans at the initial $\bar{r}^{\prime} ; \bar{r}^{\prime}$ consequently falls. In this case lenders suffer when $\mathrm{P}^{\prime}$ rises. Conversely, if the borrowers' loan demand elasticity is less than one then an excess demand for loans emerges; $\bar{r}^{\prime}$ must rise. In this case lenders benefit from the increase in $P^{\prime}$. As long as the loan market is stable, an increase in $\mathrm{P}^{\prime}$ causes $r$ to rise, so that borrowers necessarily lose.

\subsection{A Constrained Equilibrium}

Consider next the case in which, if condition (13) were to hold with equality, then borrowers' debt-service obligations would exceed the burden of the penalty. The amount that lenders would receive in retirement would be determined by the size of the penalty $P$ plus the value of bank equity, ${ }^{\prime} P^{\prime}$. The relationship 


$$
\left(1+\bar{r}^{\prime}\right)\left[w^{l}-c_{l}^{y}\left(w^{l}, \bar{r}^{\prime}\right)\right]=n\left(P+P^{\prime}\right)
$$

consequently determines the lenders' interest rate. As long as $c_{l}^{0}$ is noninferior the left-hand side of expression (15) rises with $\bar{r}^{\prime}$. Consequently $\vec{r}^{\prime}$, and thus lenders' welfare, increases when either the default penalty, $P$, or the cost of imposing the penalty, $P^{\prime}$, rises, i.e.,

$$
\frac{d \bar{r}^{\prime}}{d P}=\frac{d \bar{r}^{\prime}}{d P^{\top}}=\frac{n}{d c_{l}^{0} / d r^{\prime}} \geq 0
$$

Borrowers' utility is given by

$$
v^{b}\left[\frac{w^{y}-c_{l}^{y}\left(w^{y}, \bar{r}^{\prime}\right)}{n}-p^{\prime}, w^{b}-p\right]
$$

The effect of an increase in the penalty of default, $P$, is

$$
\frac{d v^{b}}{d P}=v_{y}^{b}\left(\frac{-d c_{l}^{y}}{d \bar{r}^{\prime}} / \frac{d c_{l}^{0}}{d \bar{r}^{\prime}}\right)-v_{0}^{b}
$$

Borrowers lose from a more severe penalty unless lenders have highly interestelastic savings, as is the case with direct lending. The effect of an increase in the cost of imposing the penalty on borrowers 'utility is

$$
\frac{d v^{b}}{d P^{T}}=-v_{y}^{b}\left(1+\frac{d c_{l}^{y}}{d \bar{r}^{\prime}} / \frac{d c_{l}^{0}}{d \bar{r}^{\prime}}\right)
$$

which is always negative.

In summary, an increase in the cost of imposing the penalty is always detrimental to borrowers. If the default penalty constrains lending then an 
increase in this cost actually benefits lenders. Whether or not they benefit in the unconstrained case depends upon how inelastic borrowers' loan demand is. As with direct lending, an increase in the penalty itself is always to the lenders' advantage and, unless the supply of lenders' savings is highly interest elastic, to the disadvantage of borrowers.

4. A Banking Equilibrium with Production and Potential Fraud

Consider now a situation in which the income of lenders and borrowers is determined by a production process that employs labor and capital to generate output. Production is at constant returns to scale so that output per worker is a function $f(k)$ of capital per worker $k$.

Lenders are workers who earn a wage $w$ in the first period of their lives. Borrowers are firms that invest capital, employ labor and produce output. Firms are competitive.

Workers cannot invest directly in firms. The intermediation of banks is required. Workers can become investors in bank deposits, which promise a return $r^{\prime}$, or owners of banks. Bankers accept deposits. They can consume these deposits as they receive them, in which case the value of their bank equity the following period is zero. Alternatively they can invest deposits in firms, earning the marginal product of capital, pay depositors a return $r^{\prime}$, and maintain a positive value of bank equity. By assumption the only source of moral hazard is the consumption of deposits by owners of banks. If bank owners invest them then repayment on deposits is guaranteed. 5

For simplicity, assume that workers regard consumption in the first and second periods as perfect substitutes, and that the discount rate is zero. Their utility function can then be written $v\left(c^{y}+c^{0}\right)$. 
Equilibrium in the market for bank equity requires that the return on equity equal the return on deposits, $r^{\prime}$. If $r^{\prime}>0$ then all wage income is saved while if $r^{\prime}<0$ all is consumed; investment in deposits and in bank equity is then zero.

Let $\lambda_{t}$ denote the share of the population of workers in period $t$ who choose to become bankers. The value of bank equity at the end of the period is consequent ly

$$
q_{t}=\lambda_{t} w_{t}
$$

Having purchased bank equity a banker can accept deposits by offering a return $r^{\prime}$. If he chooses to act fraudulently then he consumes these deposits, receiving no investment income. His bank the subsequent period is then worthless. His lifetime utility is $v\left(d_{t}\right)$ where $d_{t}$ denotes the value of deposits. If instead he invests these deposits in firms he earns the marginal product of capital in the next period, $f^{\prime}\left(k_{t+1}\right)$. He must then compensate depositors but, having done so, he can sell his bank equity at price $q_{t+1}$. Lifetime utility is then

$$
v\left\{\left[f^{\prime}\left(k_{t+1}\right)-r_{t}^{\prime}\right] d_{t}+q_{t+1}\right\}
$$

To remove the temptation to perpetrate fraud requires that the bank owner anticipate an equity price

$$
q_{t+1} \geq\left[1+r_{t}^{\prime}-f^{\prime}\left(k_{t+1}\right)\right] d_{t}
$$

If this condition is satisfied with equality then for workers to be 
indifferent between becoming depositors or becoming bankers requires that bank equity and deposits yield the same return, or that

$$
q_{t}=\frac{\left[f^{\prime}\left(k_{t+1}\right)-r_{t}^{\prime}\right] d_{t}+q_{t+1}}{1+r_{t}^{\prime}}
$$

Investment in deposits and bank equity must exhaust workers' saving so that

$$
d_{t}=\left(1-\lambda_{t}\right) w_{t}
$$

as long as $r_{t}^{\prime} \geq 0$. Competition among firms for labor insures that

$$
w_{t}=w\left(k_{t}\right) \equiv f\left(k_{t}\right)-f^{\prime}\left(k_{t}\right) k_{t}
$$

Since bank deposits are the only source of capital

$$
k_{t+1}=d_{t}
$$

If the moral hazard constraint (20) is binding then equations (19)-(24) constitute a second-order system of difference equations with state variables $q_{t}$ and $k_{t}$ and endogenous variables $\lambda_{t}, r_{t}^{\prime}, d_{t}$ and $w_{t}$. In steady-state the values of the state variables are self-perpetuating. Denoting $\bar{x}$ as the steady-state value of variable $x$, in a steady state with $\bar{r}^{\prime}>0$ and $\bar{q}>0$ :

$$
\begin{aligned}
& \bar{q}=\frac{\left[f^{\prime}(\bar{k})-\bar{r}^{\prime}\right] \bar{k}}{\bar{r}^{\prime}} \\
& \bar{q}=\left[1+\bar{r}^{\prime}-f^{\prime}(\bar{k})\right] k
\end{aligned}
$$




$$
\bar{q}+\bar{k}=w(\bar{k})
$$

which determine $\bar{r}^{\prime}, \bar{k}$ and $\bar{q}$. .

If technology is Cohb-Douglas with capital share $\alpha$ then

$$
f(k)=k^{\alpha}
$$

The solution is then

$$
\begin{gathered}
\bar{r}^{\prime}=\frac{\alpha}{1-\alpha} \\
\bar{w}=(1-\alpha)^{1 / 1-\alpha}(2-\alpha)^{-\alpha / 1-\alpha} \\
\bar{k}=\left(\frac{1-\alpha}{2-\alpha}\right)^{1 / 1-\alpha}
\end{gathered}
$$

The share of bank equity in wealth is near zero when the capital share in production is near one. As the capital share falls to zero the proportion of bank equity in wealth rises toward one-half.

The higher the labor share, the more bankers receive in deposits relative to the return on investment in firms. The temptation to engage in fraud is consequently greater. Insuring the honesty of bankers thus requires a higher value of bank equity relative to deposits.

In contrast, if bank fraud were automatically precluded then all wage income would be invested in capital. In a no-fraud steady state:

$$
r^{*^{\prime}}=f^{\prime}(k)=\frac{\alpha}{1-\alpha}
$$




$$
\begin{aligned}
& w^{\star}=(1-\alpha)^{1 / 1-\alpha} \\
& k^{*}=(1-\alpha)^{1 / 1-\alpha}
\end{aligned}
$$

The interest rate is exactly the same as in the equilibrium in which a positive value of bank equity is required to avoid fraud, even though the wage and capital stock are higher. The higher capital-labor ratio does not imply a lower interest rate because, in the absence of potential fraud, deposits yield the marginal product of capital. In the constrained equilibrium the marginal product of capital is higher, but to provide a positive return on bank equity requires that deposits yield less than the return on capital.

\section{Conclusion}

Sustaining an equilibrium with intertemporal trade requires a mechanism to bind agents to agreements. In a domestic context the police power of the state serves this purpose for many types of transactions. In international capital markets this mechanism is less reliable. Nevertheless, institutions exist that do sustain a considerable amount of intertemporal trade without an explicit enforcement mechanism.

A borrower's incentive to maintain a reputation for creditworthiness is one mechanism to enforce repayment that has already received attention. Penalties other than a loss of reputation for creditworthiness can provide an incentive to repay, but if implementing the penalty is costly to the lender, then Pareto-improving lending may be dynamically inconsistent. The source of the inconsistency is not the absence of a penalty for default, but the 
incredibility of the lender's threat to impose the penalty.

Infinitely-lived institutions can provide agents an incentive to enforce and honor contracts that finitely-lived individuals lack on their own. Their owners' desire to maintain the value of their equity in such institutions can make commitments to undertake actions that would otherwise be dynamically inconsistent credible. For these institutions to have value requires that they earn strictly positive profits. The resulting equilibrium is affected both by the divergence between the interest rates for borrowers and lenders and by the diversion of savings into bank equity.

In fact, the reputations of institutions do appear to play important roles in many transactions, in particular those involving agents subject to different legal authorities. The brand names of the major international banks and investment houses are well-known. The functioning of many aspects of international capital markets seems to require their recognizability where transactions between anonymous agents could not be sustained. 


\section{Footnotes}

1. Eaton and Gersovitz (1981b, 1983), Gersovitz (1983) and Sachs (1984) discuss the penalties that a sovereign borrower in default may experience.

2. Sargent and Wallace (1982) apply a somewhat similar model to analyze alternative forms of bank requlation.

3. Jaffee and Russell (1976) show that an inadequate incentive to repay can lead to credit rationing. Hellwig (1977) shows that the threat to impose the optimal credit ceiling is not credible in a multi-period context.

4. Eaton and Gersovitz (1981a, 1983), Kletzer (1984) and Manuelli (1984) devise models in which the borrower's desire to maintain a reputation for creditworthiness in order to borrow again supports an equilibrium with lending. Klein and Leffler (1981) and, more formally, Dybvig and Spatt (1980) and Shapiro (1983) explain a firm's incentive to provide quality on the basis of its incentive to maintain a reputation. Friedman (1971) formalizes the general notion of how, in an infinitely-repeated game, a certain degree of cooperation can be sustained by the threat of reverting to noncooperative behavior indefinitely if one player opportunistically fails to cooperate in any single period.

5. A justification for this assumption is that if investment takes place then physical capital provides security for banks and for depositors in turn. Otherwise the analysis of the previous section would have bearing as well. 
References

Dybviq, P.H. and C.S. Spatt, 1980, Does it pay to maintain a reputation? Financial Research Memorandum no. 32, Princeton University.

Eaton, J. and M. Gersovitz, 1981a, Debt with potential repudiation: theoretical and empirical analysis, Review of Economic Studies 48, 289309.

Eaton, J. and M. Gersovitz, 1981b, Poor country borrowing and the repudiation issue, Princeton Studies in International Finance No. 47, International Finance Section, Princeton University (Princeton, NJ).

Eaton, J. and M. Gersovitz, 1983, Country risk: Economic aspects, in R.J. Herring, editor, Managing international risk (New York: Cambridge University Press).

Friedman, J.W., 1971, A Non-cooperative equilibrium for supergames, Review of Economic Studies 38, 1-12.

Gersovitz, M., 1983, Trade, capital mobility and sovereign immunity, Research Program in Development Studies Discussion Paper no. 108, Princeton University.

Hellwig, M.F., 1977, A Model of borrowing and lending with bankruptcy, Econometrica 45, 1879-1906.

Jaffee, D.M. and T. Russell (1976), Imperfect information, uncertainty and credit rationing, Quarterly Journal of Economics 90, 651-666.

Klein, B. and K.B. Leffler (1981), The role of market forces in assuring contractual performance, Journal of Political Economy 89, 615-641.

Kletzer, K.M., 1984, Asymmetries of information and LDC borrowing with sovereign risk, Economic Journal 94, 287-307.

Manuelli, R., 1984, A General equilibrium model of borrowing and lending, Department of Economics, University of Minnesota.

Sachs, J., 1984, Theoretical issues in international borrowing, Princeton Studies in International Finance No. 54, International Finance Section, Princeton University (Princeton, NJ).

Samuelson, P.A., 1958, An exact consumption-loan model of interest with or without the social contrivance of money, Journal of Political Economy $66,467-482$.

Sargent, T.J. and N. Wallace (1982), The Real bills doctrine vs. the quantity theory: A reconsideration, Journal of Political Economy 90, 1212-1236.

Shapiro, C. (1983), Premiums for high-quality products as returis to reputation, Quarterly Journal of Economics 98, 659-680. 